The significance of acid

rain to agriculture in

Eastern Canada

1+. Agriculture

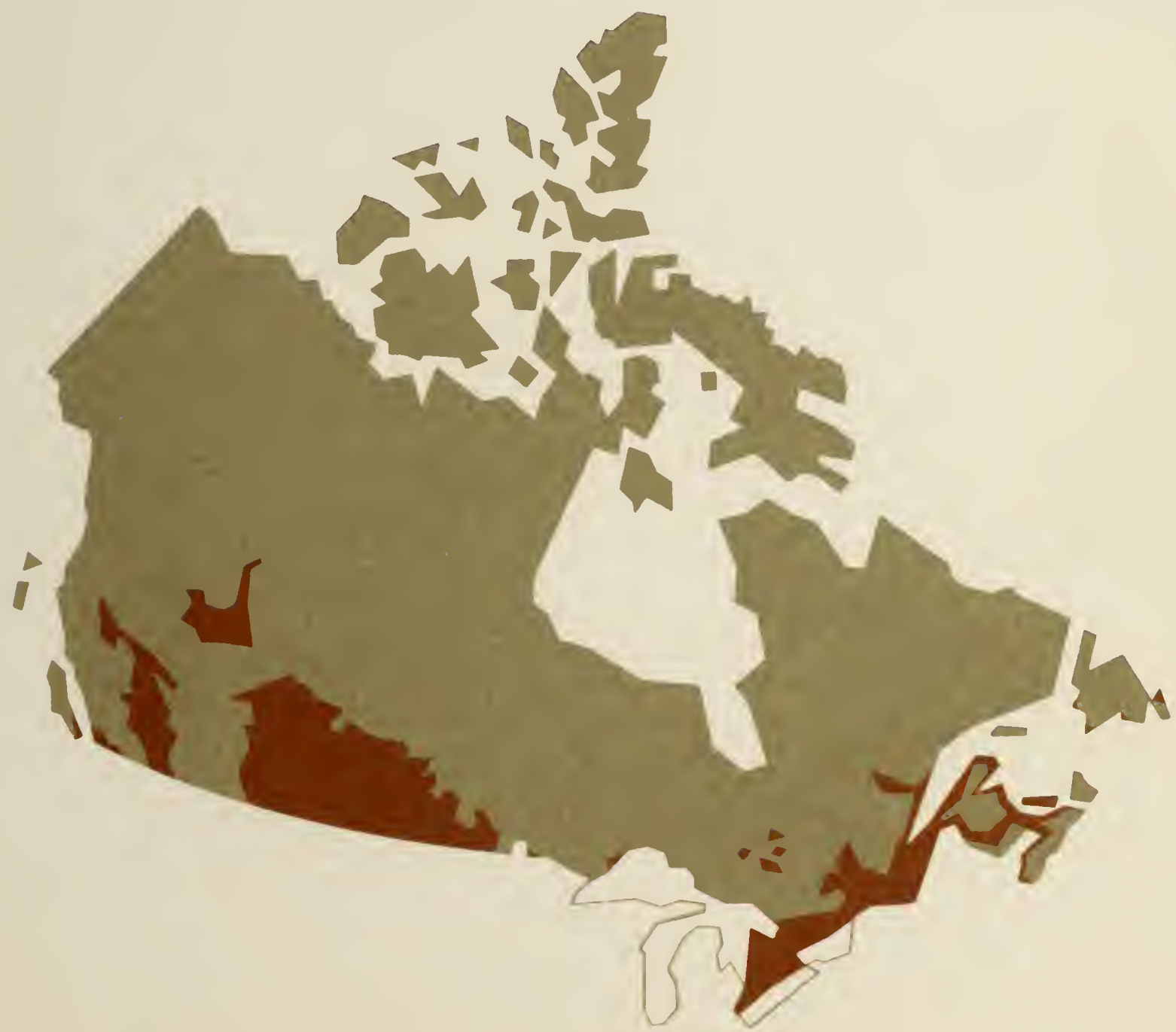

Canadian Agriculture Library

Bibliothèque canadienne de l'agriculture Ottawa K1A OC5

631.4

4253

C 119

1981

Canadäà 
Digitized by the Internet Archive in 2012 with funding from

Agriculture and Agri-Food Canada - Agriculture et Agroalimentaire Canada 


\section{The significance of acid rain to agriculture in Eastern Canada}

D. R. COOTE

Land Resource Research Institute

D. SIMINOVITCH

Chemistry and Biology Research Institute

S. SHAH SINGH

Chemistry and Biology Research Institute

C. WANG

Land Resource Research Institute

LRRI Contribution No. 119

CBRI Contribution No. 1236

Research Branch

Agriculture Canada

1981

Reprinted 1982 
Copies of thris publication are available from:

I). R. Cande

I and Resource Research Institule

Rescarch Branch

Agticulture Canada

Otlawa, Ontanio

K 1 A 0 C 6

or from:

S. Shah Singh

Chemistry and Biology Research Institute

Research Branch

Agriculture Canada

Ottawa, Ontario

Kं A 0 C6

c Minister of Supply and Services Canada 1981

Reprinted 1982 
SENSITIVITY OF AGRICULTURAL LAND TO LONG-TERM ACID

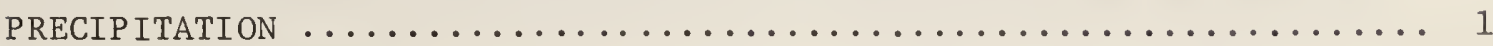

Sensitivity classes $\ldots \ldots \ldots \ldots \ldots \ldots \ldots \ldots \ldots \ldots \ldots \ldots \ldots \ldots$

Estimation of Exchangeable Bases $\ldots \ldots \ldots \ldots \ldots \ldots \ldots \ldots \ldots \ldots$

Field Guide for Determining Soil Sensitivity Classes ........ 2

The Soil Sensitivity Map $(\operatorname{Map} 1) \ldots \ldots \ldots \ldots \ldots \ldots \ldots \ldots \ldots$

Acid Rain Affecting Soils ....................... 8

EFFECTS OF ACID RAIN AND RELATED GASEOUS POLLUTION ON

CROP PLANTS

Major Atmospheric Pollutants which Affect Plants and

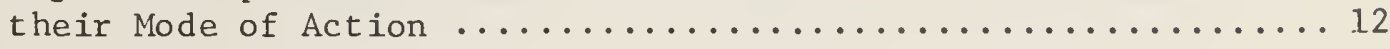

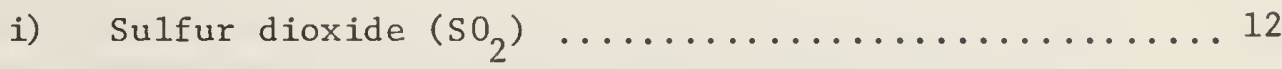

ii) Nitrogen oxides ( $\mathrm{NO}, \mathrm{NO}_{2}$ ), peroxyacyl nitrates (PAN)

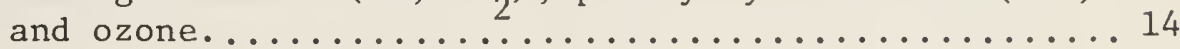

Assessment of Impact and Potential for Impact of Atmospheric

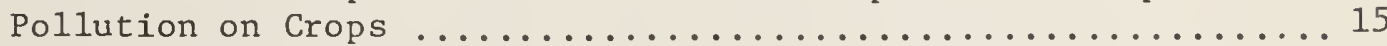

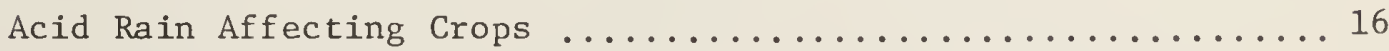

DISCUSSION AND CONCLUSIONS .......................... 19

Agricultural Concerns Related to Acid Precipitation .........21

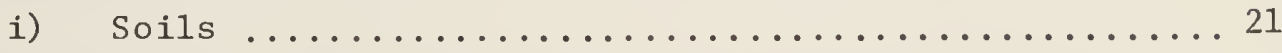

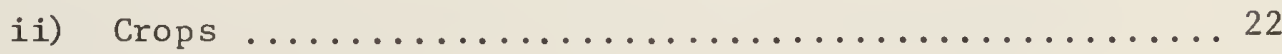

ACKNOWLEDGEMENTS $\ldots \ldots \ldots \ldots \ldots \ldots \ldots \ldots \ldots \ldots \ldots \ldots \ldots \ldots \ldots \ldots \ldots$

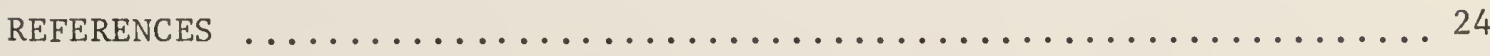


Table 1. Field guide for determining soil sensitivity to acid precipitation. .............................. 3

Table 2. Area of each sensitivity class for the agricultural land in eastern Canada......................... 7

Table 3. Sensitive crop types......................... 16

\section{FIGURE}

Relationship between soil $\mathrm{pH}\left(\mathrm{H}_{2} \mathrm{O}\right)$ and percent base saturation $\ldots . . . . .3$

\section{MAPS}

Map 1. Sensitivity of Agricultural Land to Long-Term Acid Precipitation and Estimated Mean Annual Atmospheric Deposition (Wet and Dry) of Soil-Affecting Acidity (1977-79), Eastern Canada.

Map 2. Susceptibility of Agricultural Crops to $\mathrm{SO}_{2}$ Pollution and Estimated Mean Annual Atmospheric Deposition (Wet and Dry) of Sulfur $(1977-79)$, Eastern Canada......... 17 
Precipitation falling on agricultural land in eastern Canada is contributing acid to soils and crops. In order to assess the significance of potential problems from an agricultural point of view, soil sensitivity criteria have been developed, and evidence for plant damage has been examined.

Soils were classified into sensitive, moderately sensitive and nonsensitive classes according to the estimated degree of depletion of exchangeable bases in the plow layer resulting from 25 years of acid precipitation at input rates equivalent to the highest currently being observed in the region. About $70 \%$ of the agricultural soils of eastern Canada fall into the non-sensitive class; however, twentyfive percent of the agricultural soils of Quebec are sensitive to these criteria and in P.E.I. almost all soils are sensitive or moderately sensitive.

There is little evidence of direct damage to crops from acid rain, although indirect effects resulting from soil acidification are known. There is concern, however, for potential chronic leaf tissue deterioration resulting from gaseous sulfur dioxide (a precursor of the acidity of rain) in polluted air. Synergistic interactions with other air pollutants may also result in leaf damage from $\mathrm{SO}_{2}$. Better crop and air monitoring data are needed in agricultural areas to assess these possible effects.

The components of acid rain which affect the acidity of soils include sulfates, nitrates and ammonium. Estimates indicate that the net soil-affecting acidity reaching agricultural land in eastern Canada from atmospheric deposition (wet and dry) ranges from about 25 to 40 kilograms per hectare per year when expressed as calcium carbonate (limestone) equivalent. This rate of acid addition is exceeded by two to ten times as a result of acidity from normal nitrogen fertilizer applications to crop land. Natural soil processes also contribute to acidification and to the need for lime additions to some soils.

Acidification will occur, even without acid rain, in soils which are sensitive and which are currently receiving nitrogen fertilizer without a regular lime application. In these soils the process may be somewhat accelerated by acid rain. In soils which are regularly and adequately limed, acid rain will have little effect. Constituents of air pollution which are not necessarily acid may be of greater long-term concern to soil quality and agriculture, but few data are available to assess their significance. 

Much of Canada's most productive agricultural land is located in the Great Lakes, St. Lawrence lowlands and Atlantic regions, and these are the areas of Canada in which there is greatest concern for the problem of acid rain. It is important, therefore, to examine the effects of acid rain on agricultural soils and crops, and to establish the nature and extent of any negative impacts of acid rain which may have occurred or which may manifest themselves in the foreseeable future.

This report presents the results of the preliminary assessment by Agriculture Canada of the effects of acid rain on agriculture in eastern Canada. The report discusses the problem under four main topics: the sensitivity of soils to acidification and changes in base status as a result of acid rain; the estimation of the distribution of current quantities of acid rain affecting soils; the effect of acid rain and related gaseous pollution on crop plants; and the significance of the problem to agriculture.

\section{SENSITIVITY OF AGRICUITURAL LAND TO LONG-TERM ACID PRECIPITATION}

Data available on soil characteristics relating to exchangeable bases, and assumptions based on the current state of knowledge of soil science, were used to develop a practical method of assessing soil sensitivity to acid precipj.tation (Wang and Coote 1981). The method uses soil $\mathrm{pH}$ in water and soil texture to estimate the exchangeable bases in a soil. The estimate is used to classify the sensitivity of the soil to acid precipitation.

\section{Sensitivity Classes}

Exchangeable bases in a soil reflect the soil's capacity to neutralize the acid added by precipitation. The more exchangeable bases available, the greater will be the neutralization capacity of the soil, and the less will be the influence of acid precipitation on soil $\mathrm{pH}$.

In Canadian soils the plow layer is about $15 \mathrm{~cm}$ in thickness. If it is assumed that the bulk density of the plow layer is $1.3 \mathrm{~g} / \mathrm{cm}^{3}$, and that $60 \mathrm{~kg} / \mathrm{ha}$ per year of $\mathrm{CaCO}_{3}$ equivalent is the maximum acid input (from rainfall chemistry data and dry deposition estimates), in 25 years a given soil in eastern Canada could receive a maximum of 1.5 milli-equivalents (meq) of acid from the atmosphere per $100 \mathrm{~g}$ of soil. Assuming the loss of 10 to $25 \%$ of the exchangeable bases in the plow layer is significant (McFee 1980), three soil sensitivity classes to acid precipitation can be defined: 
1. Sensitive - soil exchangeable bases are less than 6 meq/100 g soll (or more than $25 \%$ of exchangeable bases could be depleted in 25 years).

2. Moderately Sensitive - soil exchangeable bases are 6 to $15 \mathrm{meq} / 100 \mathrm{~g}$ soil (or 10 to $25 \%$ of exchangeable bases could be depleted in 25 years).

3. Nonsensitive - soil exchangeable bases exceed $15 \mathrm{meq} / 100 \mathrm{~g}$ soil

(or less than $10 \%$ of exchangeable bases could be depleted in 25 years).

Estimation of Exchangeable Bases

In calcareous surface soil it can be assumed that the buffering capacity is greater than $15 \mathrm{meq} / 100 \mathrm{~g}$ and the soil can be considered non-sensitive to acid precipitation.

In noncalcareous surface soil (soil without free carbonates), exchangeable bases are mainly controlled by CEC and soil reaction ( $\mathrm{pH}$ ). The CEC in turn is determined mainly by the amount and type of clay and by the soil organic matter. There is also an interaction between $\mathrm{CEC}$ and $\mathrm{pH}$ in any given soil, complicating the prediction of exchangeable bases in noncalcareous soils. Nevertheless, the following assumptions were made in order to permit an estimation of the base status of soils for the purpose of establishing sensitivity classes.

1) Types of clay minerals in surface soils of Eastern Canada are similar.

2) The variation of average organic matter content in surface soils, if considered over large blocks of land, is relatively narrow in most of the cultivated land in Eastern Canada.

With these two assumptions, the variables used in estimating exchangeable bases are soil texture (mainly clay content) and soil pH. Soil texture is used to estimate CEC and soil pH is used to estimate percent of base saturation. The product of CEC multiplied by the percent base saturation provides a measure of the exchangeable bases in the soil.

\section{Field Guide For Determining Soil Sensitivity Classes}

For the majority of cultivated surface soils, the permanent charge CEC for various texture classes is: clayey, $25-40 \mathrm{meq} / 100 \mathrm{~g}$; 1oamy, $10-25 \mathrm{meq} / 100 \mathrm{~g}$; and sandy, 2-10 meq/100 g. Combining this information with the general relationship between soil $\mathrm{pH}$ and percent base saturation (see Figure) provides a field guide for assessing approximate soil sensitivity to acid precipitation (Table 1). 


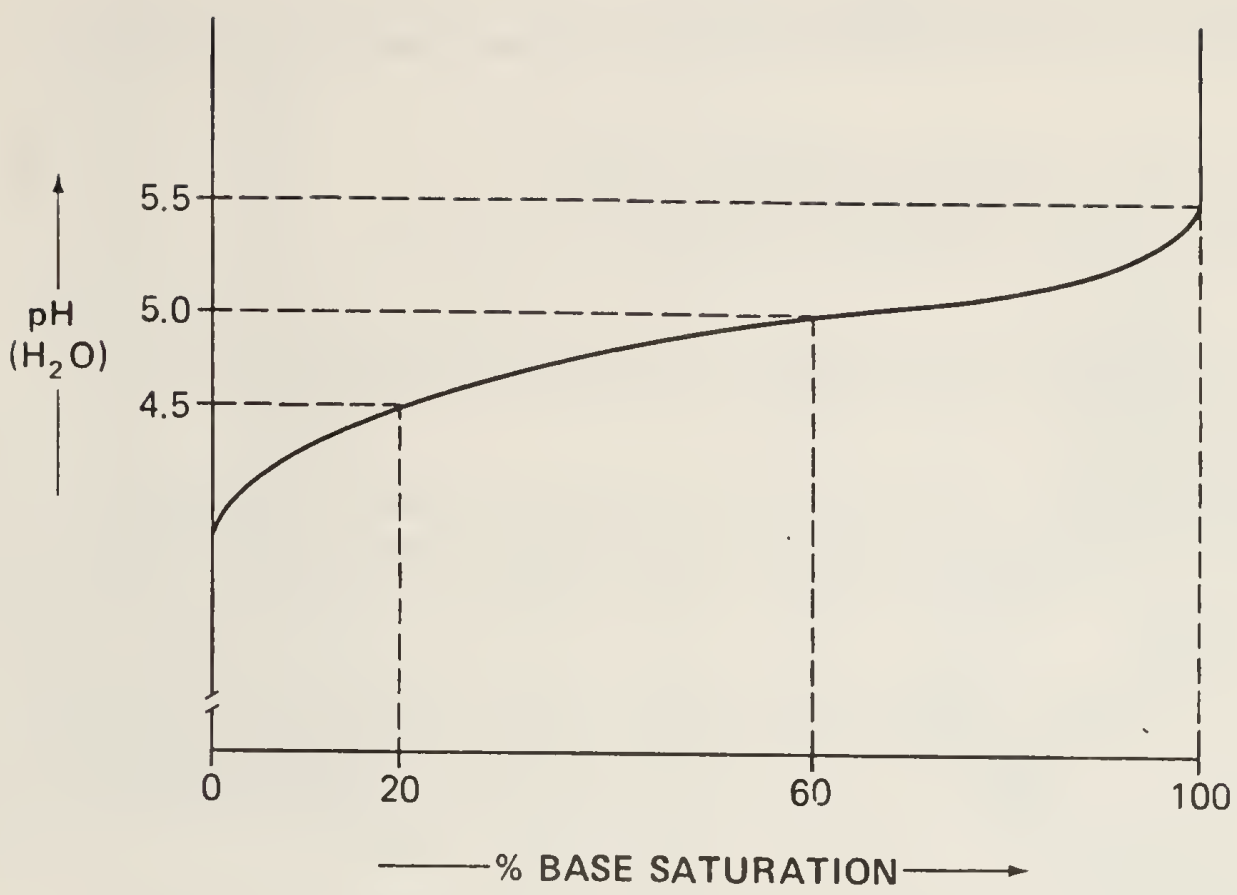

Relationship between soil $\mathrm{pH}\left(\mathrm{H}_{2} \mathrm{O}\right)$ and percent base saturation.

Table 1. Field guide for determining soil sensitivity to acid precipitation

\begin{tabular}{ll}
\hline Sensitivity class & Soil characteristics* \\
\hline Nonsensitive & All calcareous soils \\
& Clayey $\mathrm{pH}>5.0$ \\
& Loamy $\mathrm{pH}>5.5$ \\
Moderately sensitive & Sandy $\mathrm{pH}>5.5$ \\
& Clayey $\mathrm{pH} 4.5-5.0$ \\
& Loamy $\mathrm{pH} 5.0-5.5$ \\
Sensitive & Clayey $\mathrm{pH}<4.5$ \\
& Loamy $\mathrm{pH}<5.0$ \\
& Sandy $\mathrm{pH}<5.5$ \\
&
\end{tabular}

* Plowed layer (about $15 \mathrm{~cm}$ in thickness). Also assume liming is not part of regular soll management practice. Soil pH is measured in water. 
The Soil Sensitivity Map (Map 1)

Information for the compilation of the map of soil sensitivity to long-term acid precipitation (Map 1) was obtained from the following sources:

1) Canadian Soil Information System (CanSIS)

2) Published soil survey reports and interim reports

3) Provincial soil testing laboratories

With the information on texture and $\mathrm{pH}$ of the surface layer of each map delineation, sensitivity classes were assigned to each according to the guidelines in Table 1 .

General information from the soil sensitivity map is summarized in Table 2. With the exception of Prince Edward Island, much of the agricultural land in eastern Canada is nonsensitive to acid precipitation.

Soil management practices were not considered in the preparation of the map. In properly managed farmland, farmers periodically apply lime as necessary to maintain the desired soil $\mathrm{pH}$. In such instances, the amount of acid received from acid precipitation will usually be very small compared to the amount of 1 ime normally used.

Sandy soils, such as those often used for blueberry, strawberry, tobacco and potato crops, can be sensitive to acid precipitation due to their relatively low acid buffer capacity and low pH. Consequently, good management of sandy soils is required. Organic soils in eastern Canada tend to be acid. While organic soil material has a high exchange capacity per unit weight, the low average bulk density of organic soils (about $10 \%$ of that of average mineral soils) results in these soils being relatively low in exchangeable bases. They are therefore considered to be generally sensitive or moderately sensitive to long-term acid precipitation.

Nitrogen fertilizer applications frequently contribute acidity to soils (Penney and Henry 1976), at rates which can be as much as ten times that from acid precipitation. Therefore, acidity development in sensitive soils is more likely if high rates of nitrogen fertilizer are applied. For example, most of the potato land of P.E.I. is on noncalcareous sandy soils and high rates of nitrogen fertilizer are used. It is essential to use the proper amount of 1 ime in these sandy soils to maintain the desired level of $\mathrm{pH}$. Otherwise, such soils will be depleted of exchangeable bases, and their productivity will be reduced due to lack of available nutrients.

Acidity development in soils also occurs naturally as a result of carbonic acid produced by the roots of plants, organic acids from the decomposition of organic matter in the soil, and nitrate production in cultivated agricultural land (Bache 1979). 


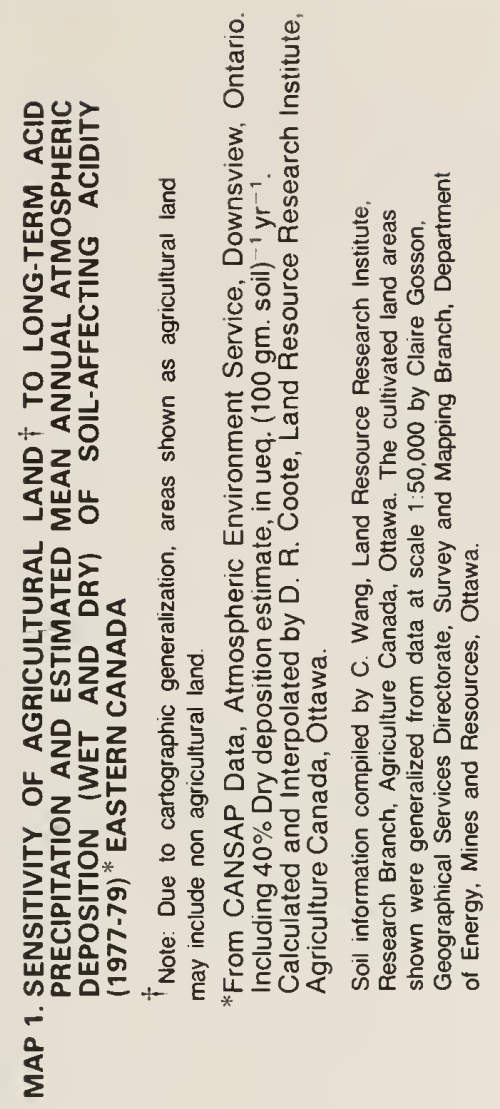

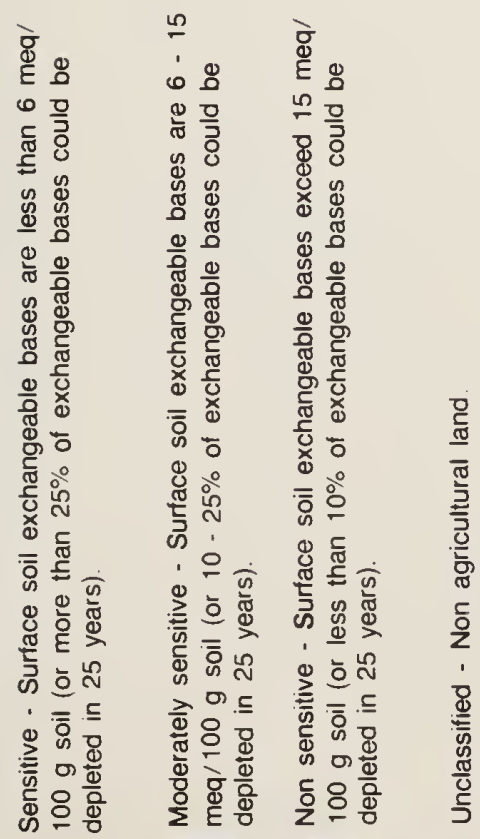

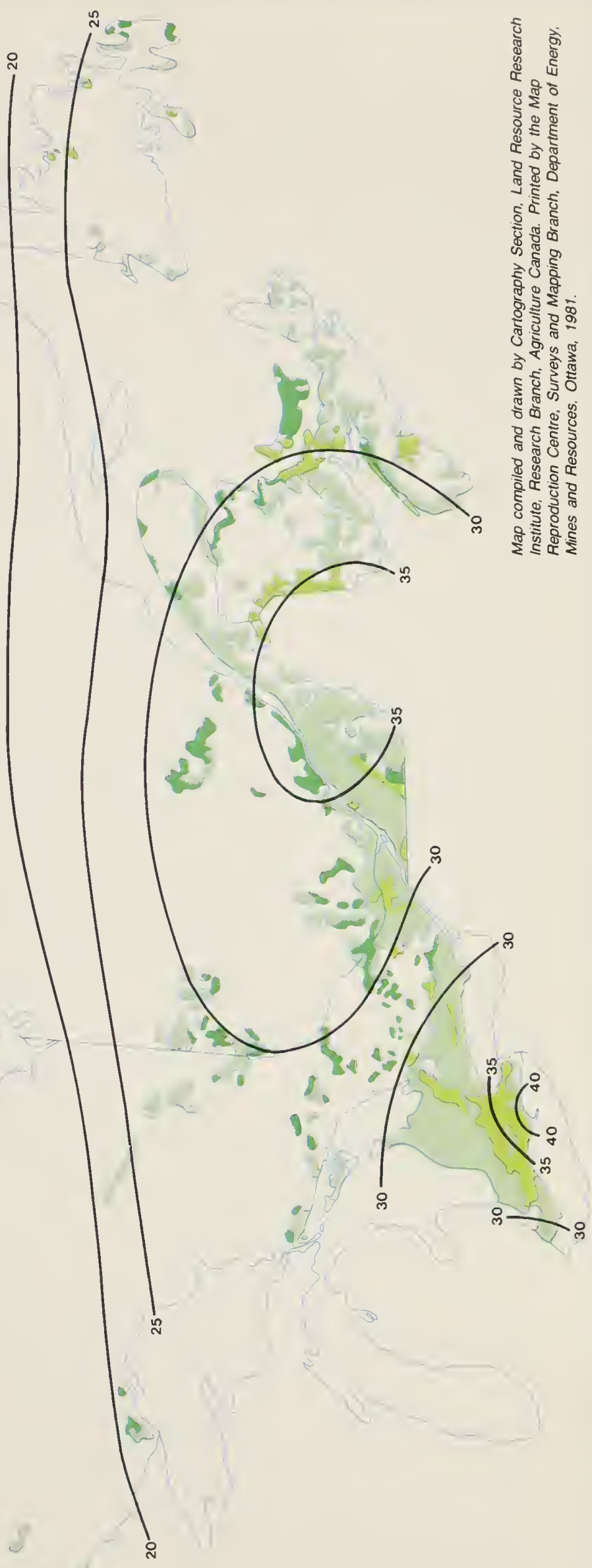





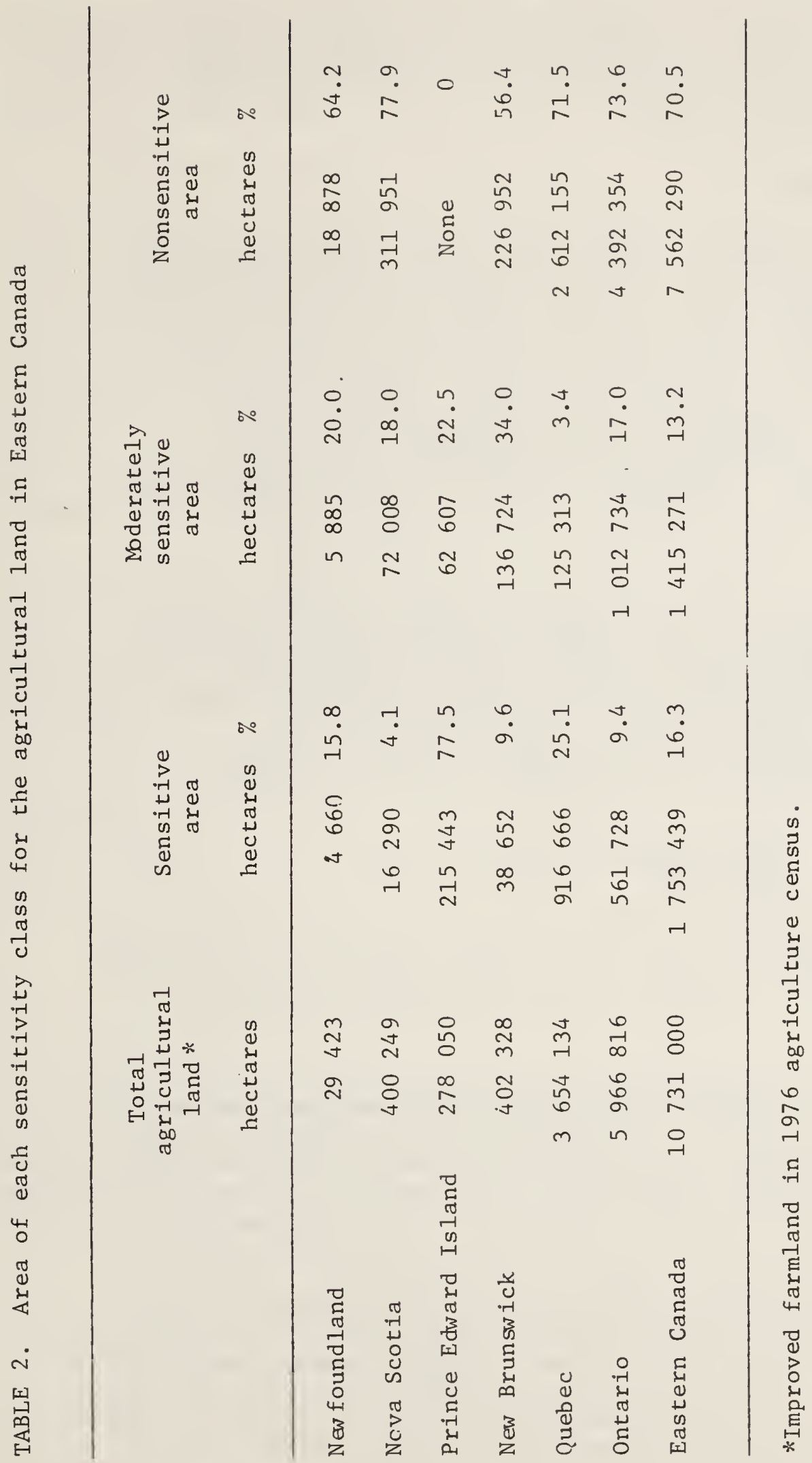


At the scale of Map 1, general information is provided only for relatively large land areas. It should not be used at the individual farm level. For smaller sections of land or for individual farms, soil sensitivity classes to acid precipitation can be estimated according to the guidelines in Table 1, following hand texturing of the soil and measurement of soil $\mathrm{pH}$ (in $\mathrm{H}_{2} \mathrm{O}$ ).

\section{Acid Rain Affecting Soils}

Estimating the acidity of rainfall and dry atmospheric deposition (generally considered together as "acid rain") as it affects the soil poses a number of difficulties. Acidity-causing atmospheric pollution in Canada has been characterized in terms of sulfur (or sulfate or sulfur dioxide) transport (Rennie 1979; Whelpdale and Galloway 1979). Indeed, most estimates of acidifying substances transported by the atmosphere have concentrated on these compounds, although there are a number of other sulfur and nitrogen compounds which will influence the acidity of rainfall and dry deposition (Grennfelt et al 1978; Fowler 1978). Whelpdale (1977) has also calculated $\overline{\mathrm{H}^{+}-\text {ion }}$ loadings to receiving land and water ecosystems from $\mathrm{pH}$ measurements.

Using either sulfur or $\mathrm{H}^{+}$-ion loadings in precipitation can be misleading when an estimate of the impact of "acid rain" on the soil is attempted. When sulfur alone is used, then the neutrality of calcium, magnesium, sodium and other such salts of sulfur is ignored. The acidic effects of nitrate and the acidity released by the. nitrification of ammonium in the soil are also omitted. The simplified reaction for the latter source of acidity is as follows (Penney and Henry 1976):

$$
\mathrm{NH}_{4 .}^{+}+2 \mathrm{O}_{2} \stackrel{\text { nitrification }}{\rightarrow} \mathrm{NO}_{3}^{-}+\mathrm{H}_{2} \mathrm{O}+2 \mathrm{H}^{+}
$$

If $\mathrm{H}^{+}$-ion load in precipitation is used, the net effect of the equilibria between $\mathrm{H}^{+}$and other ions in solution will take account of neutral salts and nitrate, but the soil acidity associated with ammonium is still ignored.

The $\mathrm{H}^{+}$-ion load, as measured by the $\mathrm{pH}$ of precipitation, seems preferable to the sulfur load if ammonium concentration data are also available to allow consideration of acidity from this source as well. Simply adding the ammonium to the $\mathrm{H}^{+}$load is not sufficient, however, to adjust for its acidifying effect because each $\mathrm{NH}_{4}^{+}$ion generates $2 \mathrm{H}^{+}$ ions on nitrification (see eqn. 1). Neither can twice this quantity be used as some ammonium is likely to be taken up directly by plant roots, though nitrate is usually taken up preferentially. When $\mathrm{NH}_{4}^{+}$is absorbed by plant roots an equivalent amount of $\mathrm{H}^{+}$is released by the root to maintain ionic equilibrium (Russell 1961). Similar mechanisms apply to nitrate taken up by roots or denitrified. These processes are neutralizing, however, as they result in the release of bicarbonate ions in root exudates, and $\mathrm{OH}^{-}$ions, respectively (Ibid.). Nitrate is readily leached from the soil, denitrified or taken up by plant roots which would tend to encourage further nitrification and favour the acidifying process. However, when $\mathrm{NO}_{3}^{-}$from nitrification or in precipitation is taken up or denitrified, the neutralizing effect must also be considered. 
Some $\mathrm{NH}_{4}^{+}$is fixed by clay minerals and organic matter, which tends to reduce the cation exchange capacity, which in turn reduces soil buffering capacity. Ammonium may also dissociate to $\mathrm{NH}_{3}$, to be volatilized or fixed by organic matter, and this also tends to be an acidifying process.

To make an estimate of the contribution of atmospheric $\mathrm{NH}_{4}^{+}$and $\mathrm{NO}_{3}^{-}$to soil acidity it is necessary to make some assumptions about the extent of nitrification, denitrification and leaching. Measured values for these variables cover wide ranges. For example, Russell (1961) reported nitrification rates of 2 to 60 percent of added $N$, dependent on soil moisture, temperature, $\mathrm{pH}$ and oxygen levels; leaching losses were reported ranging from 2 to 31 percent of added $\mathrm{N}$; and combined leaching and gaseous losses were reported as 0 to 69 percent. Brady (1974) presented data indicating that under idqeal moisture and temperature conditions nitrification of applied $\mathrm{NH}_{4}^{+}$can be essentially 100 percent. Cameron et al (1977) estimated average combined leaching and denitrification losses at 0 to 48 percent of total $N$ sources in three southern ontario soils.

If, for purposes of generalization, it is assumed from the above data that 50 percent of nitrogen added to the soil as ammonium is nitrified, and of this quantity $30 \%$ is leached and $10 \%$ is lost by denitrification, then the net effect of these pfocesses will be that the soil derives about $1.15 \mathrm{H}^{+}$ions for each $\mathrm{NH}_{4}^{+}$ion delivered in precipitation. The following schematic equation illustrates the deriviation of this net value:

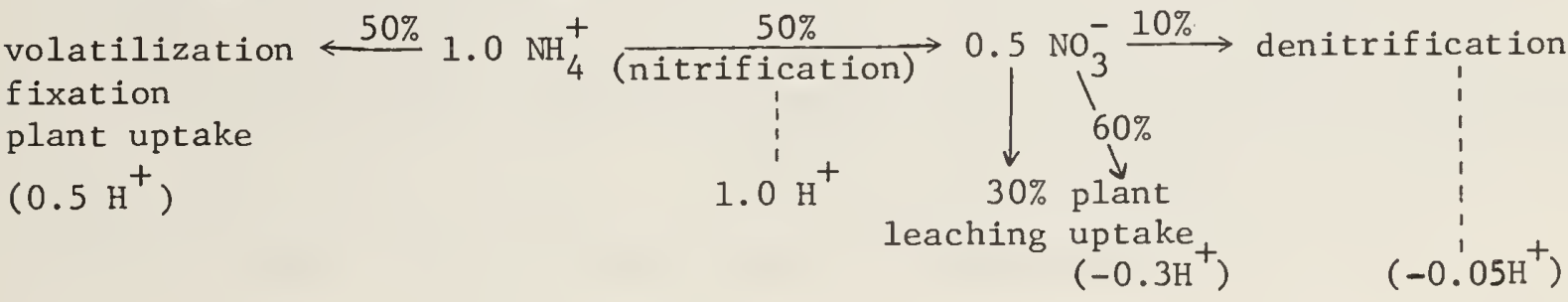

$$
\text { Net } \mathrm{H}^{+}=0.5+1.0-0.3-0.05=1.15
$$

Using the same assumptions, about $70 \%$ of the nitrate direct from precipitation will be taken up or denitrified, with the release of 0.7 neutralizing equivalents per equivalent of nitrate. This quantity must therefore be subtracted from the $\mathrm{H}^{+}$-ion load calculated from $\mathrm{pH}$ and ammonium levels. The procedure outlined above avoids the use of sulfur when estimating soil-affecting atmospheric acidity, and has been used in this report.

The problem of acidity from dry deposition introduces the greatest uncertainty into the estimation of the net input of atmospheric acidity, primarily because it is difficult to measure. Dry deposition of sulfur in eastern Canada has been calculated to be about 40 percent of the wet deposition based on air concentrations and deposition velocities (Whelpdale and Galloway 1979). This estimated percentage is lower than that for the eastern U.S. (Ibid.), but about the same as that for southern Norway (Overrein 1977). Nyborg and Walker (1977) ind icated that 
in summer in central Alberta, more sulfur was deposited in the dry particulate form than in rain, but that these particulates tended to be neutral salts. However, sorption of sulfur dloxide by soils occurred readily; and oxidation to sulfate was rapid, resulting in soil acidification. Direct sorption of ammonium and gas-phase nitric acid no doubt has similar effects after nitrification, but at present these are even more difficult to measure than sulfur dioxide dry deposition. Furthermore, the soil itself is a source of volatilized $\mathrm{NH}_{3}$ and nitrogen oxides.

In order to arrive at a reasonable estimate of the acidity arising from dry deposition, it is necessary to make further assumptions:

Fowler (1978) has reported that the dry deposition rates of both gaseous and particulate nitrogen oxides should be at least as great as those of sulfur dioxide. Thus it is reasonable to assume that the approximate eastern Canada dry deposition rate of 40 percent of wet deposition for sulfur can also be applied to the "net $\mathrm{H}^{+}$-ion" loading calculated for all forms of sulfur and nitrogen in wet deposition. This also accounts for neutral salts of sulfur because it is based on $\mathrm{H}^{+}, \mathrm{NO}_{\overline{3}}$ and $\mathrm{NH}_{4}^{+}$ions rather than simply on the sulfur content of precipitation.

Precipitation chemistry ( $\mathrm{pH}$, conductivity and 8 major ions) data have been collected monthly at 50 locations in Canada since 1977 by the Atmospheric Environment Service CANSAP program (Berry 1979). They have been used to prepare the estimate of wet and dry atmospheric deposition for eastern Canada shown on Map 1. The data have been processed according to the assumptions discussed above. The "net $\mathrm{H}^{+}$-ion" concentration values were corrected $\left(C_{S}\right)$ for differences between sampler catch and monthly total precipitation, following an A.E.S. procedure (personal communication, D. Whelpdale, A.E.S., Downsview, Ont.) as follows:

$$
\mathrm{C}_{\mathrm{S}}=\left(\left\{\mathrm{H}^{+}\right\}+1.15\left\{\mathrm{NH}_{4}^{+}\right\}-0.7\left\{\mathrm{NO}_{3}^{-}\right\}\right)\left(1+\mathrm{P}_{\mathrm{C}} / \mathrm{P}_{\mathrm{S}}\right) / 2
$$

where: $\left\{\mathrm{H}^{+}\right\},\left\{\mathrm{NO}_{3}\right\}$ and $\left\{\mathrm{NH}_{4}^{+}\right\}$are the measured concentrations of hydrogen, nitrate and ammonium ions, respectively, in monthly accumulated precipitation samples in moles/litre; and $\mathrm{P}_{C}$ and $\mathrm{P}_{S}$ are the quantity of monthly accumulated precipitation in millimetres in the sampler and in an adjacent standard rain gauge, respectively. This correction assumes that poor catch (aerodynamic influence and sensitivity of sampler activation control) and evaporation are equally responsible for $\mathrm{P}_{\mathrm{C}}$ usually being less than $\mathrm{P}_{\mathrm{S}}$.

Annual deposition $\left(D_{a}\right.$, in moles $\times 10^{4} /$ ha) was then found as follows:

$$
\mathrm{D}_{\mathrm{a}}=1.4\left(\sum_{\mathrm{s}=1}^{\mathrm{n}} \mathrm{C}_{\mathrm{s}} \cdot \mathrm{P}_{\mathrm{s}}\right) \mathrm{P}_{\mathrm{a}} / \sum_{\mathrm{s}=1}^{\mathrm{n}} \mathrm{P}_{\mathrm{s}}
$$


where $\mathrm{P}_{\mathrm{a}}$ = annual total precipitation from standard rain gauge (including snow estimates) in millimetres and $n=$ number of months sampled. The results were then expressed as milli-equivalents of $\mathrm{H}^{+}$per $100 \mathrm{~g}$ of plowlayer soil (assuming the average plow layer is $15 \mathrm{~cm}$ thick and has a bulk density of $1.3 \mathrm{~g} / \mathrm{cm}^{3}$ ). Data were available for 1977,1978 and 1979. The resulting acidity has been plotted and the distribution is presented on Map 1.

This distribution clearly shows the influence of the westerly prevailing winds transporting atmospheric acidity from the industrial areas of the Central U.S. and Ontario across southern Ontario into the St. Lawrence Valley, where additional acidity is derived from the industry of this area and southern Quebec. As the air mass moves further east, deposition and dispersion lead to progressively lower inputs of acidity to the soil.

Another process which should be considered is the loss of precipitation by direct runoff of rainfall and snowmelt over the soil to streams with little opportunity for soil acidification. In Eastern Canada, stream flow varies from about 25 percent of precipitation in southwestern Ontario to about 75 percent in Nova Scotia (Fisheries and Environment Canada 1978). Of this streamflow, estimates in southern Ontario indicate that about 55-70 percent occurs as overland runoff (Whitely and Ghate 1978), which is similar to that indicated by summer data for Nova Scotia (Pender and Jones 1969). The runoff component in spring is likely to be higher. Thus the average percentage of atmospheric acidity which never enters the soil may vary from as low as 14 percent in southwestern Ontario to about 50 percent in Nova Scotia. While this factor cannot be used to estimate acidifying atmospheric inputs to a specific soil area without knowledge of the runoff characteristics of that area, it does indicate that the average inputs will be less than those estimated from precipitation chemistry (Map 1), especially in the Atlantic Provinces.

\section{EFFECTS OF ACID RAIN AND RELATED GASEOUS POLLUTION ON CROP PLANTS}

"Acid Rain" has become a popular term which frequently covers a wide range of air pollution components which are not necessarily either acid in reaction or dissolved in rain. Since the long-range transport of atmospheric pollutants (LRTAP) is usually considered in conjunction with acid rain, it is discussed here in terms of those components which affect crop plants.

Emissions from industrial, energy-generating and urban activities continue to present a threat to the quality of our environment and to our forest and agricultural resources. A high proportion of the damage done by atmospheric pollution derives from acid generated in rain by gaseous pollutants such as $\mathrm{SO}_{2}$. While evidence exists of destruction of life in lakes and of damage to forests in Canada due to this pollution, no hard evidence exists of damage on any appreciable scale to the yield of agricultural crops. 
Experiments have been conducted on a laboratory scale in efforts to simulate the effects of acidity in rain on crop plants (Lee et al 1980), but corresponding effects in the field have not been well documented (Neumann 1980). On the other hand, injury to crop plants by gaseous $\mathrm{SO}_{2}$ in the laboratory has been duplicated under field conditions in places where atmospheric pollution by $\mathrm{SO}_{2}$ is present in similar concentrations (Katz and Ledingham 1939). Damage to crop plants and diminished yield must be anticipated in all areas where gaseous $\mathrm{SO}_{2}$ pollution is present and increasing. The assessment of the effects of acidity per se in rain is more difficult but must be weighed not only in terms of direct effects on foliage but also as long-term effects due to increases in the acidity of soils resulting from this fallout.

This section addresses the problem of the damaging effects of acid rain and related atmospheric pollutants on plants and ultimately on crop yields. It also considers factors required for assessing the sjgnificance of present and future impacts on crop yields.

Major Atmospheric Pollutants which Affect Plants and their Mode of Action

i) Sulfur dioxide $\left(\mathrm{SO}_{2}\right)$

Historically $\mathrm{SO}_{2}$ was the first atmospheric pollutant to be recognized as an important toxic agent to plants, and the classic studies by Katz and I.edingham (1939) were among the first comprehensive studies of $\cdot \mathrm{SO}_{2}$-derived plant injury. A quotation from Taylor (1979) reads: "On a world-wide basis $\mathrm{SO}_{2}$ is probably more responsible for vegetation injury and overall economic loss than any other air pollutant". The most common source of $\mathrm{SO}_{2}$ in the atmosphere is the combustion of fossil fuels. The effects of $\mathrm{SO}_{2}$ pollution on plants are both direct and indirect.

Direct effects: Plants and plant cells are very permeable to gases. Gaseous $\mathrm{SO}_{2}$ can injure the plant directly by entering open stomata and then being absorbed directly as a gas into the inner cells of the leaf. Conditions which limit stomatal opening also reduce $\mathrm{SO}_{2}$ injury. The cuticle of leaves constitutes a barrier and plants which have no cuticle like mosses or algae are very susceptible to $\mathrm{SO}_{2}$ and can therefore be used as effective biological test objects (Mudd and Kozlowski 1975).

Once inside plant cells, $\mathrm{SO}_{2}$ can undergo a number of transformations. The major toxicity derives from conversion to sulfites which, due to their extreme reactivity, directly interact or interfere with the photosynthetic metabolic intermediates or processes in reactions involving free radicals or superoxides. The exact nature and sequence of these reactions has not been completely resolved. Injury to the plant results, with lesions involving chloroplast damage and impairment of photosynthesis (Ibid.). Alternatively, after absorption as a gas, oxidation of $\mathrm{SO}_{2}$ in the leaf cells is followed by solution and hydration to $\mathrm{H}_{2} \mathrm{SO}_{4}$. The $\mathrm{SO}_{4}$ ion can then enter normally into many 
essential plant reactions and constituents because sulfur is an essential element in plants. However, in the event of excess absorption and after the buffering capacity of the plant has been exhausted, plant injury due to direct acidity within the plant ensues. This results in impairment of vital processes. In either case it is the gaseous $\mathrm{SO}_{2}$ and its entry through stomata which is the initial and important step in the sequence of reactions which lead to the major injury, and not the direct fallout and wetting of the surface of leaves by acid rain formed in the atmosphere.

Critical discussions of direct injury of plants by $\mathrm{SO}_{2}$ deal almost exclusively with the gaseous component and its effects after entry through the stomata and uptake by the interior mesophyll cell (Ibid.; Nriagu 1978). This leads to the impairment of photosynthesis and damage to chloroplasts and cells. Generally, the symptoms are lesions and discoloration of the leaves with inevitable reduction in crop yields. The effects can be immediate (acute injury due to the sulfite) or chronic (due to cumulative absorption of $\mathrm{SO}_{4}$ beyond threshhold buffering capacity) (Linzon 1978). The extent of $\mathrm{SO}_{2}$ absorption is evidenced by estimates (Bennett and Hill 1975) indicating that a continuous cover of assimilating alfalfa can remove $88 \mathrm{~kg}$ of $\mathrm{SO}_{2}$ per square kilometer per day from the atmosphere with a mean concentration of $\mathrm{SO}_{2}$ similar to that over a 5000 square kilometer area in the vicinity of Sudbury. Total absorption would be greater in perennials like trees or alfalfa than in annuals and less in cropped plants than in trees or shrubs.

Rennie and Halstead (1977) reviewed 23 references reporting threshold and/or tolerable concentrations of $\mathrm{SO}_{2}$ in the atmosphere. The reported levels appeared to decrease with time, with the more recent references (1971-1972) reporting the lowest concentrations. These were about 0.05 ppm (about $180 \mu \mathrm{g} \mathrm{m}^{-3}$ ) for agricultural crops and even lower for some tree species. While these levels are considerably higher than have been found in preliminary monitoring of gaseous $\mathrm{SO}_{2}$ levels in remote rural areas of eastern Canada, they are only marginally higher than those often observed in Toronto (Barrie, L.A., Wiebe, H.A., Fellin, P., Anlauf, K., AES, Downsview, Ont., unpublished data, 1980). Thus the potential for damage from $\mathrm{SO}_{2}$ near urban areas and other sources is evident.

Long-range transport of $\mathrm{SO}_{2}$ has also been demonstrated (Barrie et al 1980; McBean 1980). With the deficiencies in rural monitoring data from areas such as southern Ontario and southern Quebec, and the probability of synergistic effects of $\mathrm{SO}_{2}$ with other air pollutants, it is therefore reasonable to reserve judgement on $\mathrm{SO}_{2}$ impacts on the yields of agricultural crops until more data are available.

Many laboratory studies have attempted to demonstrate direct injury to leaves by simulation of acid rainfall. In the laboratory prolonged exposures of foliage to $\mathrm{pH}^{\prime}$ s more acid than those of rainfall are needed to elicit any clear symptoms of damage (Lee et al 1980; Neumann 1980). The results are inconclusive at common $\mathrm{pH}^{\prime} \mathrm{s}$ of natural rainfal1 (Neumann 1980; Evans and Curry 1979). 
Indirect effects: The indirect effects of $\mathrm{SO}_{2}$ on plants are of equal and possibly greater importance on a long-term basis than the direct effects. They are drawing increased attention because of their protracted and persistent features. Linzon (1978) has noted that the effect of acid precipitation is on soils rather than on foliage. The injurious consequences of increases in acidity of the soil are varied. There are strict 1 imits to the growth of plants at acid $\mathrm{pH}^{\prime} \mathrm{s}$. Soils or solutions with pH values less than 4.0 are directly toxic to plant roots. Minimum pH values for good growth of crops (Nyborg 1975) range from 6.2 for alfalfa to $\mathrm{pH} 4.6$ to 5.0 for grasses, with the values for most crops being above $\mathrm{pH}$ 5.0. Since rain water in eastern Canada is often in the $\mathrm{pH}$ range of 4.0 to 5.0 , it follows that without adequate buffering properties in soils there exists a real possibility of injury. High soil acidity affects the total chemistry of soils and consequently influences the growth of plants in a number of ways. Depending on the species, plants may suffer from toxic levels of Al and $M$ n due to increases in their solubility in acid soils. Nyborg (1975) emphasizes that, due to a considerable increase in solubility, Al can become toxic at pH 5.5. Symbiotic nitrogen fixation is also sensitive to $\mathrm{pH}$ (personal communication, S. Mathur, CBRI, Agriculture Canada), since both nodulation and nitrogen fixation are retarded by low $\mathrm{pH}$. In general, acid pH's are detrimental to microbiological processes in the soil.

While it is clear direct gaseous $\mathrm{SO}_{2}$ absorption from the atmosphere presents a concern for agricultural crops, it is also becoming increasingly evident that cumulative acidity in the soil from acid rain and other sources such as fertilizers will probably have a greater influence. In terms of remedial or corrective measures, however, hope is offered for 1 imitation of acid rain impacts through changing agricultural practices including selecting by breeding for more acid soil tolerant plants, shifting cropping programs to better suit sensitive areas and more directly through liming.

\section{ii) Nitrogen oxides ( $\mathrm{NO}, \mathrm{NO}_{2}$ ), peroxyacyl nitrates (PAN) and ozone}

The nitrogen oxides and their derivative toxicants produced photochemically, and by industrial and combustion processes, represent another category of pollutants in the atmosphere. To some extent the concerns with $\mathrm{SO}_{2}$ apply also to nitrogen oxides. However, as far as gaseous injury by nitrogen oxides is concerned the effect on plants is not the same as $\mathrm{SO}_{2}$ and plants will not exhibit the same sensitivity to nitrogen oxides as they do to $\mathrm{SO}_{2}$. Indeed Taylor (1979) states that nitrogen oxides have a low level of phytotoxicity. On the other hand, nitric oxide produced in combustion can be oxidized in the atmosphere to nitrogen dioxide, which can react photochemically with hydrocarbons to produce ozone and peroxyacyl nitrate (PAN). Ozone and PAN are destructive to vegetation in the presence of hydrocarbon pollution. Damage by ozone ( $f$ lecking) in certain regions is now well documented but evidence of widespread local occurrences, by contrast with effects of $\mathrm{SO}_{2}$, has not been well established. 
Assessment of Impact and Potential for Impact of Atmospheric Pollution on Crops

There are two necessary approaches to the problem of pollution damage to crop plants in Canada. One is the assessment of the present and potential future damage to crop plants and the other is the possible remedial or corrective measures which might be taken to ameliorate or avoid such damage. Corrective or remedial measures, other than those of control at the source of emissions, will depend on the results of the damage assessment.

In respect to damage to crop plants, the major category is the direct damage incurred from penetration of the plant tissues by gaseous sulfur dioxide, nitrogen oxides and probably ozone. Based on the available evidence, the direct effect of acid fallout on foliage surfaces need not be a source of great concern for the moment. The results of simulated acid fallout on foliage in laboratory experiments do not appear to be conclusive, and $\mathrm{pH}$ values of rainfall seldom fall to those at which negative effects on plants have been observed (AES 1977-79; Lee et al 1980). Indirect effects resulting from cumulative acidification of the soil environment may weil override the injuries inflicted either by wet or dry fallout on the surfaces of plants (Neumann 1980). The effects of ozone gas generated by photochemical interaction of nitrogen oxides with hydrocarbons should not be ignored but, at the present time, emphasis must be on the effects of $\mathrm{SO}_{2}$ and nitrogen oxides as gases and on their contribution to acidification of rain water.

The following information will be needed for a complete assessment of air pollution effects on agricultural crops:

a) Routine gathering of data on intensity and scope of pollution by regular monitoring or sampling of the atmosphere in rural regions exposed to the paths of emissions from active centres of industrial or combustion activities. This monitoring should encompass direct analysis for gaseous $\mathrm{SO}_{2}$ and nitrogen oxides in the atmosphere and measurements of rates of assimilation by plants (deposition velocities) at different physiological stages. 1

b) Statistical data on distribution and intensity of cultivation of important crops. Knowledge of the relative sensitivity of these crop plants to gaseous $\mathrm{SO}_{2}$ can then be used to calculate a weighted estimate of the degree of possible impact on the agricultural economy of air pollution. Malvern, Paterson and Grey (1980) have made an initial attempt at this task for Ontario. They used the term "sensitivity crop index" for the weighted value which they arrived at from such calculations. They suggest that if it is possible to superimpose data on the distribution of $\mathrm{SO}_{2}$ pollution for Ontario on the map of sensitivity crop index, an estimate of the pollution risks in ontario can be obtained. Table 3 shows some relative crop sensitivity estimates based on the table prepared by Malvern et al (Ibid.).

Agriculture Canada and the Province of Alberta have initiated some cooperative studies of these factors (personal communication, R.L. Desjardins, LRRI, Agriculture Canada, Ottawa). 
Map 2 has been prepared to show the distribution of sensitive crops, wefghted by factors reflecting the crop values and the degree of specialization of soil and climate needs of each crop type (Table 3 ). The map presents the distribution of each of the crop types listed in Table 3, in percent of farmland multiplied by the appropriate factor. This serves to emphasize those crops which are most valuable and/or have the most specific soll and climate needs, making it more difficult to relocate production if atmospheric pollution damage becomes excessive. While it is desirable to plot rural gaseous $\mathrm{SO}_{2}$ concentrations on this map, these data are not presently available. Instead, estimates of the total sulfur deposition have been plotted, but only to give a gross indication of areas most likely to be influenced by $\mathrm{SO}_{2}$, and not as an estimate of $\mathrm{SO}_{2}$ per se.

c) Data are available to reflect the effect of acid rain on the soil which in turn will affect the viability and growth of the crop plants. The sensitivity of the soils in various regions of eastern Canada to changes in $\mathrm{pH}$ due to acidity in rain fallout has been compiled and presented on Map 1, along with an estimate of soil-affecting acidity from precipitation.

Table 3. Sensitive crop types*

Crop group Assigned rating value

Fruit and vegetables 4

White beans 3

Soyabeans 2

Grains and alfalfa 1

$* \quad$ After Malvern et al (1980); Rating is based on economic value and degree of specialization of soil and climate needs with respect to each crop type, with tobacco and sweet corn excluded as they are sensitive only to ozone.

Acid Rain Affecting Crops

Data for maintaining an up-to-date assessment of $\mathrm{SO}_{2}$ levels in the atmosphere are sparse. There are many sources of atmospheric sulfur which contribute to sulfur in acid rain (Fowler 1978). It has also been shown that there is a correlation between atmospheric $\mathrm{SO}_{2}$ and dissolved $\mathrm{SO}_{2}, \mathrm{HSO}_{3}$ and $\mathrm{SO}_{3}^{=}$in rain water (Gravenhorst et al 1978), but 1 is not clear whether there is a reliable relationship with $\mathrm{SO}_{4}$ or total $\mathrm{S}$ in rafn water. Thus precipitation $\mathrm{SO}_{4}$ cannot be used as a surrogate for gaseous $\mathrm{SO}_{2}$. Nevertheless, some studies have related precipitation $\mathrm{SO}_{4}$ to atmospheric $\mathrm{SO}_{2}$ emmissions (Malvern et al 1980; Acres Consultants 1977), and others have demonstrated that atmospheric $\mathrm{SO}_{2}$ can be related to distant as well as local sources (McBean 1980; Barrie et al 1980). It is therefore reasonable to expect that areas 

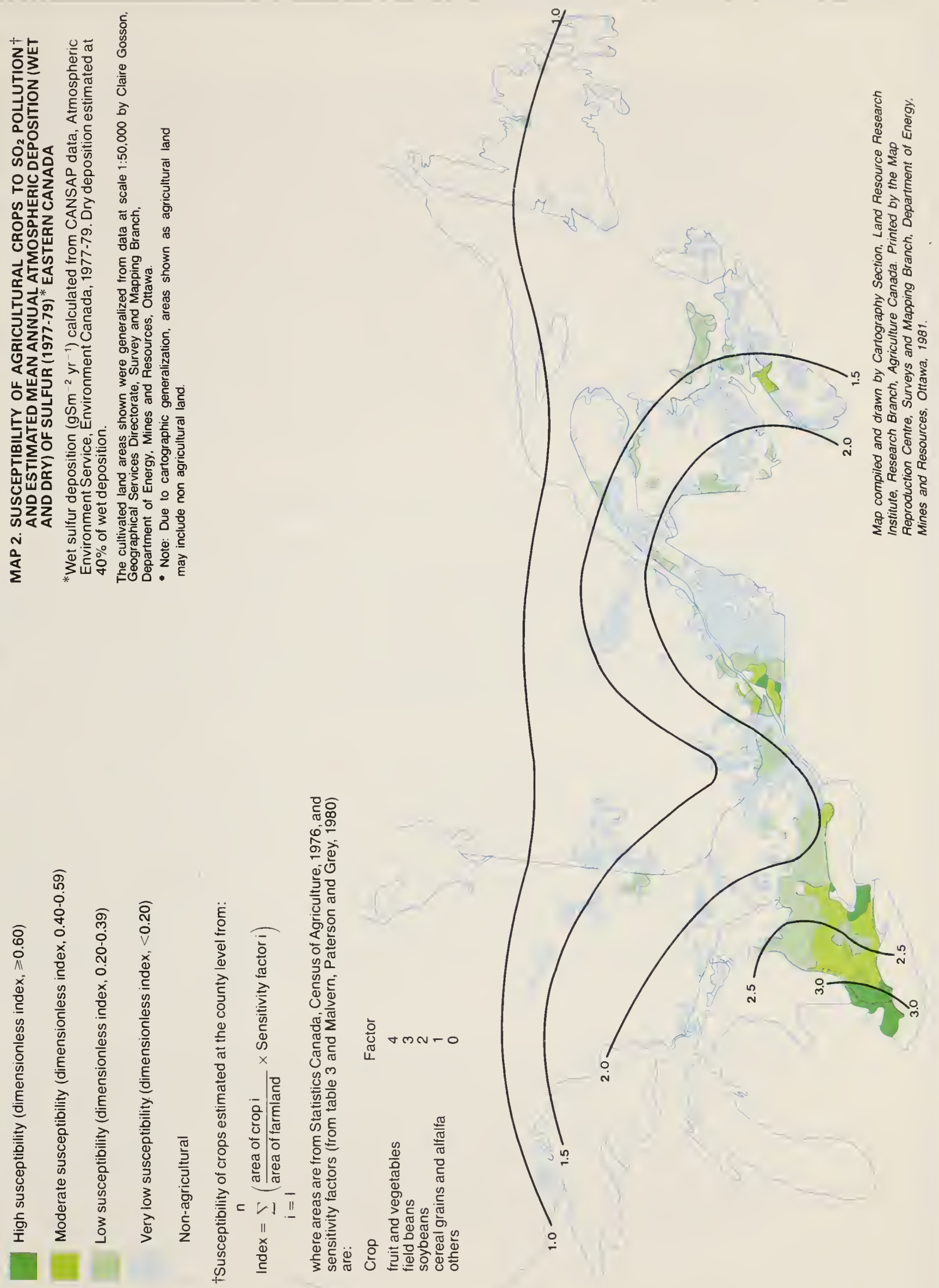

with high total sulfur levels in atmospheric deposition will be more likely to have higher gaseous $\mathrm{SO}_{2}$ levels than those with lower total $\mathrm{S}$ deposition. Indeed, comparison of the unpublished data of Barrie, Wiebe, Fellin and Anlauf (AES, Downsview, Ont., 1980) with CANSAP sulfate levels indicate relative agreement when the urban data from Toronto are excluded. In the absence of further data, CANSAP sulfur data do appear to give some indication of areas in which plants may be subjected to air pollution. The sulfur content of rainfall samples collected in the CANSAP program is given only as $\mathrm{SO}_{4}$, and since other data on dry deposition in eastern Canada are not available, it is necessary to use these data as interim indicators of total sulfur fallout. By using the $40 \%$ dry deposition estimate extracted from Whelpdale and Galloway (1979), an initial evaluation of the distribution of total sulfur deposition over agricultural land can be made from the CANSAP data base. This distribution is presented on Map 2, but it cannot be used quantitatively.

\section{DISCUSSION AND CONCLUSIONS}

It is reasonable to assume that as long as precipitation has fallen on the surface of the earth, it has been somewhat acidic in nature. The intensity of this acidity has depended on the presence of various elements in the atmosphere. Under ideal conditions which occur only under relatively few circumstances, the $\mathrm{pH}$ of rain should be about 5.6. This is based on the mean concentration of $\mathrm{CO}_{2}$ in the atmosphere. The other major components of the atmospheric air, namely $\mathrm{N}_{2}$ and $\mathrm{O}_{2}$, do not react readily with rain water except under special circumstances, where $\mathrm{N}_{2}$ is converted to oxides of $\mathrm{N}$.

The situation described above has rarely existed since the appearance of man on this earth. Since the industrial revolution the emission of contaminants into the atmosphere has been increasing steadily and interfering more and more with the natural environment. Nitrogen and sulfur are two such elements which are discharged into the atmosphere in a variety of different chemical forms and are of particular concern in increasing the acidity of rain. The emissions of pollutants return to earth as dry deposition or combined with rain water. Acidity in precipitation results from the presence of acids, mainly $\mathrm{H}_{2} \mathrm{SO}_{4}$ but also $\mathrm{HNO}_{3}$ and $\mathrm{HCl}$. Ammonium ions ( $\mathrm{NH}_{4}$ ) are also transformed by nitrification into $\mathrm{HNO}_{3}$.

The presence of acidity in rain water has become an international concern because of damage to the environment both near and distant from the sources of these pollutants. A good example is Sweden, where 77 percent of the atmospheric $S$ has its source outside the country. Similarly, pollutants from the industrial area of the central USA, Ontario and Quebec are carried to the Atlantic Provinces. The consequences of global acid precipitation will be alarming if it continues uncontrolled. The production of pollutants will increase as the standards of living of developing nations rise in the coming years. 
The impact of acid precipitation is relevant to agriculture because it clearly results in increased soil acidity. Hcwever, soils are a complex dynamic environment. The severity and significance of acid precipitation have to be evaluated with respect to other changes occurring in soils. Hydrolysis of cations is an acid-producing reaction continuously occurring in soils. In soils located in cold climates, where processes of formation are slow and reactions are in harmony with nature, the sudden change in one parameter will most likely influence others. With our current krowledge of soil management and soil formation, the acidification of soils situated in fragile environments should be considered undesirable.

For the soils which are under cultivation for agricultural crops, the impact of acid rain has to be evaluated with respect to increasing soil acidity due to management practices. For example, the soils of southwestern Ontario have been increasingly depleted of basic cations over the years and now some of these soils are acid where they were neutral about fifty years ago. At the Harrow Research Station the continous application of nitrogen fertilizers to corn has decreased the $\mathrm{pH}$ of some plots to 4.8 compared with a pH of 6.8 under control treatments.

Application of commercial fertilizer to agricultural soils has been increasing steadily throughout the world and many of these fertilizers produce acidic reactions in soils similar to those that occur when rain water comes in contact with acidity-producing pollutants such as $\mathrm{SO}_{\mathrm{x}}$ and $\mathrm{NO}_{\mathrm{x}}$. Thus evaluation of the impact of acid precipitation on soils also requires consideration of the soil type; location of the area; factors of soil formation already prevailing; maturity of the soils; and current use and soil management practices of the area.

The probable values of atmospheric acid inputs to soils of eastern Canada are in the range of 20 to $40 \mu \mathrm{eq} / 100 \mathrm{~g}$ soil per year (wet and dry). When expressed in terms of 1 ime, this is equivalent to a $\mathrm{CaCO}_{3}$ content of 20 to $40 \mathrm{~kg} / \mathrm{ha}$ per year. Based upon these present levels of acidity from pollutants in precipitation, it is reasonable to conclude that changes in $\mathrm{pH}$ due to this process will be modest on agricultural soils and are of little consequence where liming is one of the agricultural management practices. As well as contributing to rainfall acidity, sulfur is a macronutrient so that which enters the soil via the atmosphere can be used by plants. Where soils are inadequately supplied with sulfur through mineralization of organic matter or weathering of parent materials, atmospheric sources may substitute for sulfur soil amendments.

The effect of atmospheric pollutants on vegetation may be due to direct contact with $\mathrm{SO}_{\mathrm{x}}$ and $\mathrm{NO}_{\mathrm{x}}$ emissions and due to contact with acidic precipitation, as well as the indirect effect of acid soils on root systems. Gaseous $\mathrm{SO}_{\mathrm{x}}$ appears to have a greater effect on plants compared with surface deposition, and a number of crops are susceptible to damage by air pollution through this route. The few data which are available for rural areas suggest that ambient $\mathrm{SO}_{2}$ concentrations are well below those which have been established for damage to most crops. 
However, the paucity of data, and the possibility of synergistic effects among air pollutants, leaves little opportunity to evaluate the overall significance of present or future $\mathrm{SO}_{2}$ effects on crop yields. It must therefore be concluded that a cautious position is indicated, until further data are available. Little evidence has appeared to support the concept of significant direct foliar damage by acid rain. There is some question, however, of the possible weakening of the resistance of plant foliage to attack by fungi, viruses and insect pests. These fears have not been adequately justified up to the present time. The type of vegetation is an important consideration in discussion of the above effects, e.g. the impact may well be different on perennial vegetation such as forests compared with annual vegetation such as agricultural crops.

There is limited information on the effect of pollutants on agricultural crops on a field scale. However, in recent years some work has been reported under laboratory conditions. For a proper evaluation it seems especially important for agricultural crops that observations be extended to field conditions. The dynamic nature of the environment cannot be investigated in isolation. The effects will depend upon the duration of exposure, wind conditions, temperature and physiological states of crop canopies (deposition velocities), and the amount and rate of precipitation, amangst. others.

There is another question which may merit discussion and consideration with respect to acidity and crop breeding. On a global scale, acidity is on the increase in most productive agricultural soils. Crop varieties developed to give optimum performance at a $\mathrm{pH}$ of 6 , for example, are being grown where soil $\mathrm{pH}$ has decreased to 5. Can we develop crop varieties which will give better performance at $\mathrm{pH} 5$ ?

\section{Agricultural Concerns Related to Acid Precipitation}

\section{i) Soils}

The impact of acidic precipitation is modest on agricultural soils as compared to the prevalent soil fertility management practices (e.g. application of nitrogen fertilizers). However, we should be aware that the rates and amounts of emissions of acid-forming pollutants may increase in future. Agronomists should concern themselves with total acidity development in soils (all sources) and with changes taking place in the soil environment. The development of soil acidity, if not controlled and if not maintained at a suitabie level, can result in dissolution of clay minerals, decrease in cation exchange capacity, increase in fixation of plant nutrients, release of toxic elements, etc. There is general consensus amongst soil scientists that soil management practices for most crops are acidity forming when liming is not a component of the program.

Some of the concerns with regard to soil acidity are:

- to evaluate the present status of our agricultural soils with respect to soil reaction $(\mathrm{pH})$;

to evaluate the role of management practices in the development of soil acidity; 
- to establish the soil pH which will be least destructive to the soil/ plant environment and will maintain optimum base saturation status; to assess the need for a built-in mechanism for maintaining soil acidity at a certain level when making fertilizer recommendations (e.g. liming included to neutralize the acidity due to fertilizer application).

Map 1, showing the sensitivity of agricultural soils in eastern Canada and the probable soil-affecting acid input from the atmosphere, can be used to identify areas of higl load and high sensitivity. Ir general, the highest loadings coincide with areas of least soll sensitivity. Exceptions to this generalization are the sandy soils along the north shore of the St. Lawrence river in Quebec and some areas in the Shield region of south-central Ontario. Other areas to note are the moderately sensitive sandy soils of southwestern Ontario and western New Brunswick which fall into high acid fallout zones. Unpublished data have been compiled by the senior author* to show the distribution of nitrogen fertilizer use and applications of lime in eastern Canada. It is noteworthy that most of the sensitive soils east of the Kingston, Ontario area receive sufficient lime, on average, to offset inputs of acidity from both fertilizers and acid rain. This is not the case, however, in southwestern Ontario where susceptibility to acid rain persists in the moderately sensitive sandy soils of the region.

\section{ii) Crops}

Our knowledge of the effects on crops of prevailing atmospheric conditions, during growing periods, is limited. This applies both on a field scale and also under controlled conditions. For the evaluation of the effects of $\mathrm{NO}_{\mathrm{x}}, \mathrm{SO}_{\mathrm{x}}$ and acidity of rain, reliable information is needed from which to establish relevant experiments. Total amounts of pollution over a certain period (e.g. for a year) are of limited value. Improved monitoring and research programs are required for: the deposition velocities for gaseous pollutants and how these are affected by variations in the physiological conditions of crop canopies; the concentration of gases in the air; the $\mathrm{pH}$ of rain and variation in $\mathrm{pH}$ with time; the pattern of rainfall and how concentrations of pollutants vary with different stages of crop growth. There are some programs already in effect where this type of monitoring information is being collected. Agriculturalists should use these data in evaluating the influence of pollutants on agricultural crops. In conjunction with these, field observations should be made during the growing period of various crops and related to the atmospheric conditions and components.

* An Assessment of the Degradation of Agricultural Land in Canada. D.R. Coote, J. Dumanski, J.F. Ramsey. Research Branch, Agriculture Canada, Ottawa (manuscript in preparation). 
Map 2 shows the distributions of weighted crop sensitivities to atmospheric $\mathrm{SO}_{2}$ and shows that southwestern Ontario and the area south of Montreal have the greatest density of the more valuable and specialized sensitive crops. These two areas are also clearly those with the highest sulfur deposition levels and hence, by association, must be assumed to be those with the highest probability of atmospheric $\mathrm{SO}_{2}$ pollution. These two areas, therefore, are those in which direct damage to crops may be of greatest potential significance.

\section{ACKNOWLEDGEMENTS}

We would like to thank Mrs. Lendvay-Zwickl and Mr. Leuty of the Land Resource Research Institute for providing us with information from the CanSIS file. Thanks also are extended to Dr. Beke, Mr. MacDougall and Mr. Cossette of the Soil Survey of Canada, and to the Provincial Soil Testing Laboratories of P.E.I., Nova Scotia, New Brunswick, Quebec and Ontario for providing summaries of their surface soil pH data for agricultural land. The assistance of Mr. John Ramsey, Ms. Lucie Mongeon, Ms. Karen Burns and Ms. Doris Kostolvik, of the Land Resource Research Institute, with the preparation of this report is gratefully acknowledged. 



\section{REFERENCES}

Acres Consultants. Atmospheric loading of the lower Great Lakes and the Great Lakes Drainage Basin. Pollution from Land Use Activities Reference Group, IJC, Windsor, Ont. 70 pp.; 1977.

Atmospheric Environmental Service. CANSAP Data Summary. Environment Canada, Downsview, Ont. (quarterly); 1977 to 1979.

Bache, B.W. The acidification of soils. Pages 183-202 in T.C. Hutchinson and M. Havas, eds. Effects of acid precipitation on terrestrial ecosystems. Proc. of NATO Adv. Res. Inst. Conf., Toronto; 1979.

Barrie, L.A.; Weibe, H.A.; Anlauf, K.; Fellin, P. The Canadian air and precipitation monitoring network APN. Pages 355-360 in Proc. 14 th Int1. Colloqu. Paris, May 5-8. M.M. Bernarie ed., Studies in Environmental Science, Vol. 8; 1980.

Bennett, J.H.; Hill, A.C. Interactions of air pollutants with canopies of vegetation. Pages 273-306 in J.B. Mudd and T.T. Kozlowski, eds. Responses of Plants to Air Pollution. Academic Press; 1975.

Berry, R.L. The Canadian Network for Sampling Precipitation (CANSAP) Project. Atmospheric Environment Service, Environment Canada, Downsview, Ont. 9pp.; 1979.

Brady, N.C. The nature of properties of soils, 9th Ed. MacMillan, N.Y., Chap. 16; 1974 .

Cameron, D.R.; Neilsen, G.J.; Culley, J.L.B.; DeJong, R.; Findlay, W. Nitrogen movement in tile-drained clay and sandy agricultural watersheds. Final Report, Project 13, Agricultural Watersheds Studies, PLUARG, IJC, Windsor, Ont. $97 \mathrm{pp} . ; 1977$.

Evans, L.S.; Curry, T.M. Differential responses of plant foliage to simulated acid rain. Am. J. Botany 66:953-962; 1979.

Fisheries and Environment Canada. Hydrologic Atlas of Canada. Supply and Services Canada, Ottawa; 1978.

Fowler, D. Wet and dry deposition of sulphur and nitrogen compounds from the atmosphere. Pages 9-27 in T.C. Hutchinson and M. Havas, eds. Effects of acid precipitation on terrestrial ecosystems. Proc. NATO Adv. Res. Inst. Conf. Toronto, Ont.; 1978 .

Gravenhorst, G.; Beilke, S.; Betz, M.; Georgii, H-W. Sulfur dioxide absorbed in rain water. Pages 41-56 in T.C. Hutchinson and M. Havas, eds. Effects of acid precipitation on terrestrial ecosystems. Proc. NATO Adv. Res. Inst. Conf., Toronto, Ont. 1978. 
Grennfelt, P.; Bengston, C.; Skarby, L. An estimation of atmospheric input of acidifying substances to a forest ecosystem. Pages 29-40 in T.C. Hutchinson and M. Havas, eds. Effect of acld precipitation on terrestrial ecosystems. Proc. NATO Adv. Res. Inst. Conf. Toronto, Ont.; 1978 .

Katz, M.; Ledingham, G.A. (several papers in) Effect of sulphur dioxide on vegetation. Bul1. 815, N.R.C., Ottawa; 1939.

Lee, J.J.; Needly, G.D.; Perrigan, S.C. Sulfuric acid rain effects on crop yields and foliar injury. U.S. Environmental Protection Agency Report No. 600/3-80-016; 1980.

Linzon, S.N. Effects of a fr-borne sulphur pollutants on plants. Pages 109-162 in J.0. Nriagu, ed. Sulphur in the environment, Pt. II, Ecological impacts. John Wiley and Sons; 1978.

Malvern, R.J.; Paterson, W.M.; Grey, G.D. An approach to mapping air pollution sensitive crops in Ontario. Ontario Hydro. 73rd Air Poll. Control Assoc. Ar. Meeting, Montrea1, June 25; 1980.

McBean, G.A. Long-range transport and deposition of acidic substances across national boundaries. AES, Downview, Ont., 73rd Air Pol1. Cont. Assoc. An. Meeting, Montrea1, June 22-27; $198 \mathrm{C}$.

McFee, W.W. Sensitivity of soil regions to long term acid precipitation. U.S. Environmental Protection Agency Report No. $600 / 3-80-013 ; 1980$.

Mudd, J.B.; Kozlowski, T.T., eds. Responses of plants to air pollution. Academic Press; 1975.

Neumann, H.H. Meteorological conditions associated with a ir pollution injury to plants. Pages 118-121 in Proc. A.E.S. Workshop on Agromet., U. of Guelph; 1980.

Nriagu, J.0., ed. Sulphur in the environment, Pt. II, Ecological impacts. John Wiley and Sons; 1978.

Nyborg, N. Sulfur pollution and soll. Pages 359-390 in J.0. Nriagu, ed. Sulfur in the environment, Pt. II, Ecological impacts. John Wiley and Sons; 1975.

Nyborg, M.; Walker, D.R. An overview - the effects of sulphur dioxide emmission on the acidity and sulphur content of soils. Pages 165-195 in H.S. Sandu and M. Nyborg, eds. Proc. Alta. Sulphur Gas Research Workshop III, U. of Alta, Edmonton; 1977.

Overrein, L.N. Acid precipitation - impacts on the natural environment. Pages 1-6 in H.S. Sandu and M. Nyborg, eds. Proc. Alta. Sulphur Gas Research Workshop III, U. of Alta., Edmonton; 1977.

Pender, G.F.; Jones, J.F. Determination of the groundwater component of peak discharges from the water chemistry of total runoff. Water Resources Research 5(2):438-445; 1969. 
Penney, D.C.; Henry, J.L. Reaction of fertilizer $\mathrm{N}$ with soil components. Pages 275-298 in Proc. Western Canadian Nitrogen Symp., Alta. Soil Sci. Workshop, Calgary; 1976.

Rennie, P.J. The susceptibility of eastern Canadian terrestrial ecosystems to long-range pollution. Canadian Forestry Service, Environ. Can., Ottawa (Unpublished); 1979.

Rennie, P.J.; Halstead, R.L. The effects of sulfur on plants in Canada. Pages 69-179 in Sulphur and its inorganic derivatives in the Canadian environment. National Research Council Canada. NRCC No. 15015; 1977.

Russell, E.W. Soll conditions and plant growth. Longmans, London, 9th Ed. Chap. 22; 1961.

Taylor, 0.C. Phytotoxic air pollutants and their sources. Symp. on the Effects of Airborne Pollution on Vegetation; E.C.E., Warsaw, Poland; 1979.

Wang, C.; Coote, D.R. Sensitivity classification of agricultural land to long-term acid precipitation. Research Branch, Agriculture Canada, 9pp.; 1981.

Whelpdale, D.M. Regional-scale measurements of precipitation, composition and deposition. Paper Pres. at W.M.O. meeting, Boulder, Colorado, U.S., August 20-24, Atmos. Environ. Serv., Environ. Can., Downsview, Ont.; 1977.

Whelpdale, D.M.; Galloway, J.N. An atmospheric sulphur budget for North America. Paper pres. at W.M.0. meeting, Sofia, Bulgaria, Oct. 1-4, Atmos. Environ. Serv., Environ. Can., Downsview, Ont.; 1979.

Whitely, H.R.; Ghate, S.R. Hydrologic Model Project. Final Report, Project 15, Agricultural Watershed Studies, PLUARG, I.J.C., Windsor, Ont. 100 pp.; 1978. 



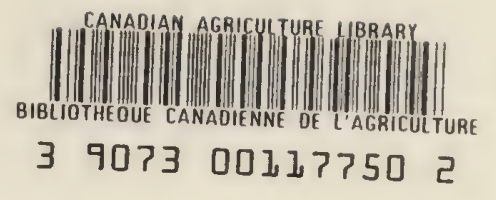


